\title{
STUDY OF RHEOLOGY OF YEAST DOUGH WITH PROTEIN-CARBOHYDRATE ADDITIVE
}

\author{
Svitlana Popova \\ Department of technology in the restaurant sector and the hotel and restaurant business \\ Mykhailo Tugan-Baranovsky Donetsk National University of Economics and Trade \\ 16 Ostrovskyi str., Kryvyi Rih, Ukraine, 50005 \\ Rez_ok@mail.ru \\ Alina Slashcheva \\ Department of technology in the restaurant sector and the hotel and restaurant business \\ Mykhailo Tugan-Baranovsky Donetsk National University of Economics and Trade \\ 16 Ostrovskyi str., Kryvyi Rih, Ukraine, 50005 \\ sl-alina.2011@ya.ua \\ Radion Nykyforov \\ Department of technology in the restaurant sector and the hotel and restaurant business \\ Mykhailo Tugan-Baranovsky Donetsk National University of Economics and Trade \\ 16 Ostrovskyi str., Kryvyi Rih, Ukraine, 50005 \\ nikradion@yandex.ua

\section{Yurii Korenets} \\ Department of technology in the restaurant sector and the hotel and restaurant business \\ Mykhailo Tugan-Baranovsky Donetsk National University of Economics and Trade \\ 16 Ostrovskyi str., Kryvyi Rih, Ukraine, 50005 \\ yuriy_korenec@mail.ru
}

\begin{abstract}
The aim of the studies was the establishing of rational concentration of the dry protein-carbohydrate half-finished product (DPCHFP) in technology of yeast dough, received in accelerated way. The dough structural-mechanical properties were studied using Brabendar's farinograph and extensograph, the firm-elastic and rheological dough properties at DPCHFP presence were also studied. It was established, that DPCHFP usage in technological process of yeast dough production gives a possibility to correct the flour and purposefully influence its rheological properties. The rational DPCHFP concentration at this stage of research is $15 \%$ for the flour mass.

Keywords: dry protein-carbohydrate half-finished product, dry potato additive, yeast dough, structural-mechanical properties, rheological properties.
\end{abstract}

\section{Introduction}

The problem of bakery enrichment remains topical for today $[1,2]$. The prospective direction of its solution is the use of secondary products of milk raw material processing [3, 4].

The accelerated technology of yeast dough with increased biological value was offered [5]. It is based on the use of two additives - dry potato additive (DPA) [5] and dry protein-carbohydrate half-finished product (DPCHFP) [6]. DPA, received from the secondary products of potato processing, contains the significant quantity of reducing sugars and favors activation of yeasts in the yeast dough. DPCHFP allows enrich bakery with valuable milk protein, pectins, vitamins, essential macro- and microelements.

The double influence of milk protein [7-9] on the yeast dough and ready bakery properties $[10,11]$ needs the correct approach to the use of this ingredient.

Milk proteins have the high buffer ability that is the essential cause of decrease of the yeast dough fermentation $[12,13]$. DPA usage in complex with DPCHFP must favor elimination of this problem because it raises the life activity of yeasts, intensifies the process of gasification in dough and provides the increase of its specific volume at fermentation. DPA includes reducing sugars, 
necessary for the running of biochemical and microbiological processes. Acceleration of fermentation is also favored by the addition of the significant number of nitrous and mineral substances that improve the yeasts nutrition from DPCHFP. Thus DPCHFP addition to the yeast dough needs the obligatory studies of their influence on rheological properties.

\section{Materials and Methods}

The base of complex researches is the establishing of the optimal DPCHFP concentration depending on the rates of structural-mechanical and rheological parameters of the yeast dough.

For preparation of the control sample the receipe of ferment-free yeast dough according to [14] was used. For the studied samples the receipe of ferment-free yeast dough with addition of DPA at the stage of yeasts activation in quantity $5 \%$ for the flour mass was used [5]. DBCHFP were also added to the samples in quantity 5, 10, 15 and $20 \%$ for the flour mass at the stage of dough mixing. The recipe composition of control and studied samples are presented in the Table $\mathbf{1}$.

Table 1

Recipe composition of the studied sample

\begin{tabular}{|c|c|c|c|c|c|}
\hline \multirow{3}{*}{ Raw material name } & \multicolumn{5}{|c|}{ Raw material consumption, for $1 \mathrm{~kg}$ of product in grams } \\
\hline & $\begin{array}{c}\text { Control } \\
\text { (recipes collection № 1024) }\end{array}$ & $\begin{array}{l}\text { DPCHFP } \\
5 \%\end{array}$ & $\begin{array}{l}\text { DPCHFP } \\
10 \%\end{array}$ & $\begin{array}{c}\text { DPCHFP } \\
15 \%\end{array}$ & $\begin{array}{l}\text { DPCHFP } \\
20 \%\end{array}$ \\
\hline & net & net & net & net & net \\
\hline Wheat flour of higher quality & 641 & 641 & 641 & 641 & 641 \\
\hline Pressed yeasts & 19 & 18 & 18 & 18 & 18 \\
\hline DPA & - & 32 & 32 & 32 & 32 \\
\hline DPCHFP & - & 32 & 64 & 96 & 128 \\
\hline Sugar-sand & 32 & - & - & - & - \\
\hline Culinary fat & 29 & 29 & 29 & 29 & 29 \\
\hline Dry egg powder (DEP) & 34 & 34 & 34 & 34 & 34 \\
\hline Culinary salt & 10 & 10 & 10 & 10 & 10 \\
\hline Water & 258 & 258 & 258 & 258 & 258 \\
\hline
\end{tabular}

The following sets of flour were used at the research - higher (set № 1) and I quality (set № 2), made by "Khutorok", country-producer - Ukraine.

Bakery properties of the wheat flour, used at the research, are presented in the Table 2.

Table 2

Bakery properties of the wheat flour sets

\begin{tabular}{|c|c|c|}
\hline \multirow{2}{*}{ Quality parameters } & \multicolumn{2}{|c|}{ Sets of flour } \\
\hline & Set № 1 & Set № 2 \\
\hline Moisture, \% & 13,6 & 13,9 \\
\hline Gasification ability, $\mathrm{cm}^{3} \mathrm{CO}_{2} / 100 \mathrm{~g}$ & 1450 & 1400 \\
\hline Raw gluten content, $\%$ & 32,2 & 30,1 \\
\hline Gluten firmness on apparatus VDK-1 & 59 & 77 \\
\hline Gluten extensibility, $\mathrm{cm}$ & 10 & 15 \\
\hline Acidity, degrees & 2,8 & 2,9 \\
\hline
\end{tabular}


The studied flour sets were characterized by the totality of physical-chemical parameters as the flour with the mean bakery properties, according to the requirements [15].

The structural-mechanical and firm-elastic properties of yeast half-finished products were determined using farinograph ${ }^{\circledR}$ and extensograph ${ }^{\circledR}-\mathrm{E}$, made by «Brabender», Germany. The studies were carried out in laboratories of department of bakery, confectionary, macaroni and food concentrates of Odessa national academy of food technologies (ONAFT), city Odessa, Ukraine.

«Brabender» farinograph, used for the study of structural-mechanical properties of the dough at mixing, is presented on the Fig. 1.

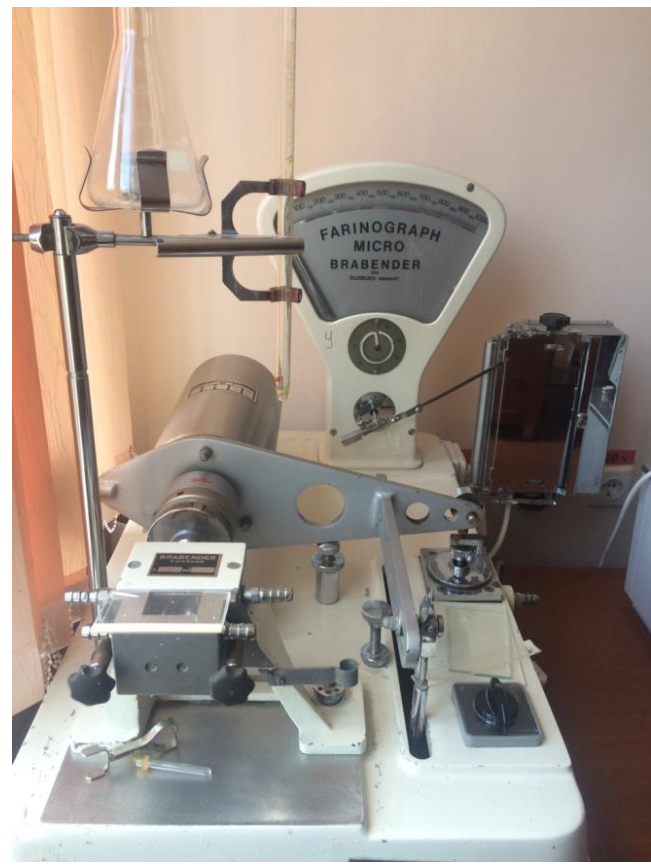

Fig. 1. Farinograph "Brabender"

The mixing of dough was made for the control example (flour, water, salt) and also for the studied samples (flour, water, salt, DPCHFP in concentration 5, 10, 15 and $20 \%$ for the flour mass).

The mixing container was filled with $300 \mathrm{~g}$ of flour with moisture 14,0\%. The mixing container was closed with cover. The heater was switched on. For determination of hydroscopic capacity of the flour, the mixing engine was switched on for $3 \mathrm{~min}$ for heating flour, the cover of mixer was taken off and $2-\% \mathrm{NaCl}$ solution was added to the flour from burette in quantity, necessary for creation of dough with consistence 500 units of far. The value of consumed $\mathrm{NaCl}$ solution was calculated by burette and expressed in \% for the flour mass $\left(\mathrm{G}_{\mathrm{m}}\right)$. This value expressed experimental hydroscopic capacity of the studied flour $\left(\mathrm{HC}_{\mathrm{exp}}\right)$. Hydroscopic capacity for the flour of basic moisture $(14,0 \%)$ was calculated by the formula (1):

$$
\mathrm{HC}_{14,0}=\mathrm{HC}_{\exp }-100+2 \mathrm{G}_{\mathrm{m}}
$$

For the experiment with studied samples the flour quantity was decreased depending on concentration of additive for the general flour mass together with additive was $300 \mathrm{~g}$.

In combination with farinograph that the dough was mixed on, extensograph «Brabender» (Fig. 2), made by Germany was used for further studies. Extensograph was used for determination of wheat flour force - it allows assess the physical properties of the dough at deformation of extension that gives a possibility to make conclusions as to the dough behavior at creaming. 


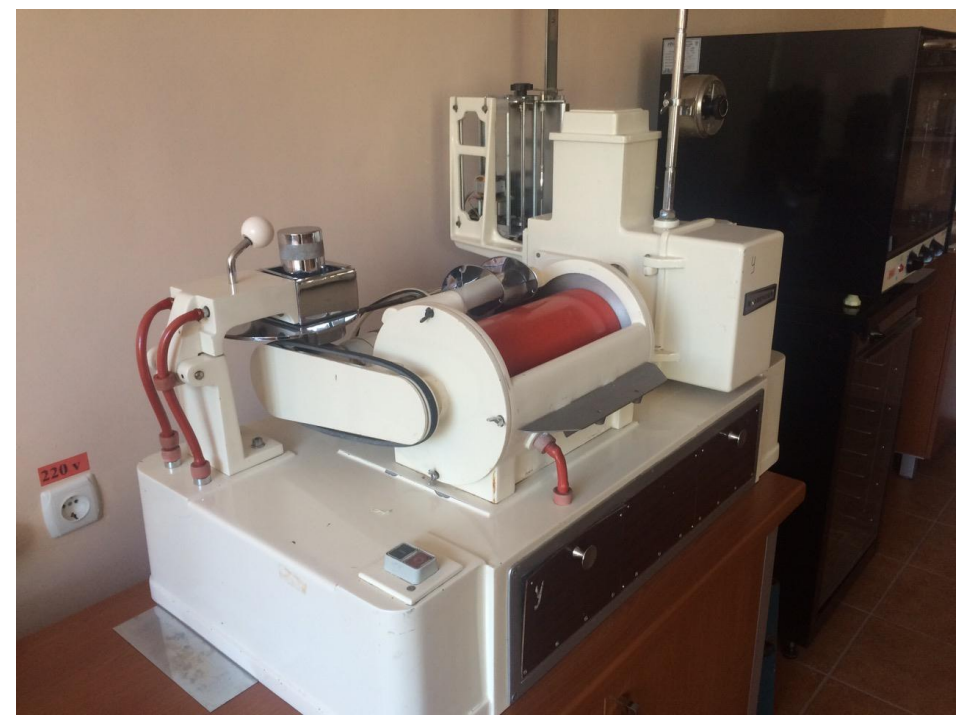

Fig. 2. Extensograph «Brabender»

Extensograph also gives a possibility to detect the additive influence on the flour that allows receive the reliable parameters of the flour rheological parameters and correct rheological optimum depending on the set tasks.

The study of rheological characteristics of dough (Fig. 3) (effective viscosity and shift tension) was carried out on the rotary viscosimeter Rheotest RN 4.1., made by «RheoTest Messgerate Medingen GmbH», Germany.

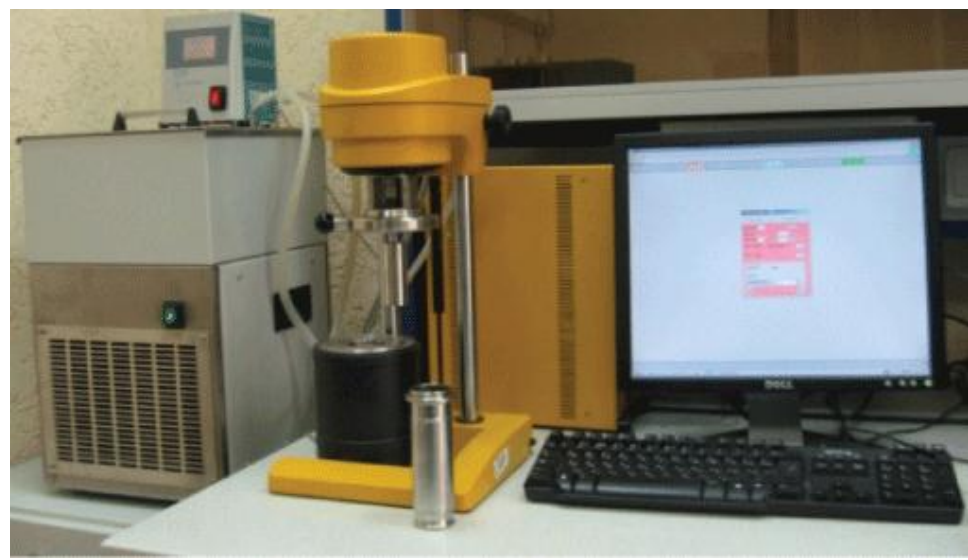

Fig. 3. Rotary viscosimeter Rheotest RN 4.1

The study was carried out in laboratory of the Department of technology in the restaurant sector and the hotel and restaurant business of Donetsk National University of Economics and Trade (DonHUET), named after Mykhailo Tugan-Baranovsky, Krivy Rig, Ukraine.

\section{1. Experimental procedures}

The principle of farinograph action is such that the more resistance of dough against the turning of kneading blades, the more inclination of the electric engine-dynamometer from its initial position. This inclination is transmitted to the recorder. The dough resistance is in direct proportion with the flour force and water quantity, consumed for the mixing. The stronger flour is, the more its hydroscopic capacity and dough consistence in the apparatus units. The example of farinogram is presented on the Fig. 4. 


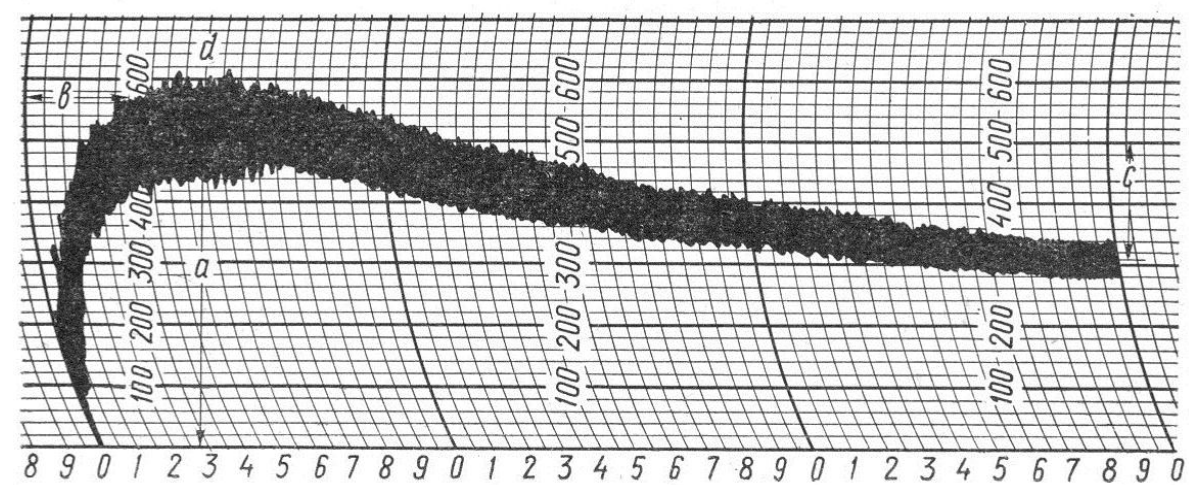

Fig. 4. Scheme of the dough mixing farinogram: $a$-dough consistence, $b$-duration of dough creation, $c$ - dough elasticity and extensibility, $d$-dough stability (steadiness), $e$ - dough dilution

The curve, delineated by the recorder of apparatus, is called farinogram, Fig. 4.

It represents the following dough properties:

- dough consistence $(a)$, units of apparatus;

- maximal value of the lift of farinogram curve;

- duration of dough creation (b), min - time, in which the dough consistence reaches its maximum;

- elasticity and extensibility $(c)$ - maximal width of curve, units of apparatus. The wider the curve is, the more elastic and tensile the dough is;

- dough stability (steadiness) $(d)$ - duration of keeping the maximal dough consistence, min;

- dough dilution $(e)$ - decrease of consistence in the final moment of mixing, comparing with the maximal consistence, units of apparatus;

The stronger the flour is, the more $b-d$ values on farinogram and the less $e$ value are.

In combination with farinograph for dough mixing, the further studies were carried out on extensograph «Brabender». This apparatus is used for determination of the dough physical properties by its resistance to the stretching efforts.

The dough was mixed of 300 of wheat flour to the consistence that corresponds to 500 units of farinograph. Then it was divided in pieces of $150 \mathrm{~g}$ using the special rounder of extensograph. The dough blanks were formed as the rectilinear cylindrical braid and placed in retainer. The formed blanks were fermented during $45 \mathrm{~min}$. all systems of apparatus were heated to $30{ }^{\circ} \mathrm{C}$ according to the requirements: "SST 4111.2-2002 Wheat flour. Dough physical characteristics. Part. Determination of rheological properties by extensograph (ISO 5530-2:1997. MOD)".

After fermentation (keeping) in the special chambers $\left(\mathrm{t}=30^{\circ} \mathrm{C}\right)$ the dough sample in retainer was set on the stretching apparatus. The effort (resistance) that appears at dough stretching is transmitted through the system of levels to the mechanism that recorder is connected to. The registering instrument is switched on synchronously with electric engine. The curve 5 is delineated on the diagram paper that demonstrates the dough resistance against one-axis stretching - extensogram. At disruption of dough braid the registering device is automatically switched off.

Extensograms after 90 and 135 min of dough samples keeping are received in the same way according to ISO 5530-2:1997. MOD (Fig. 5).

The following parameters are determined by extensogram:

- energy that is calculated by area. Area is calculated using planimeter, expressed in square centimeters;

- resistance to the stretching (firmness), measured by the extensogram height, stepped back by $50 \mathrm{~mm}$ from the start of curve $-\mathrm{P}_{\mathrm{c}}$, is expressed in units of extensograph;

- extensibility - L, is measured in $\mathrm{mm}$ by the curve length;

- resistance - extensibility ratio. 


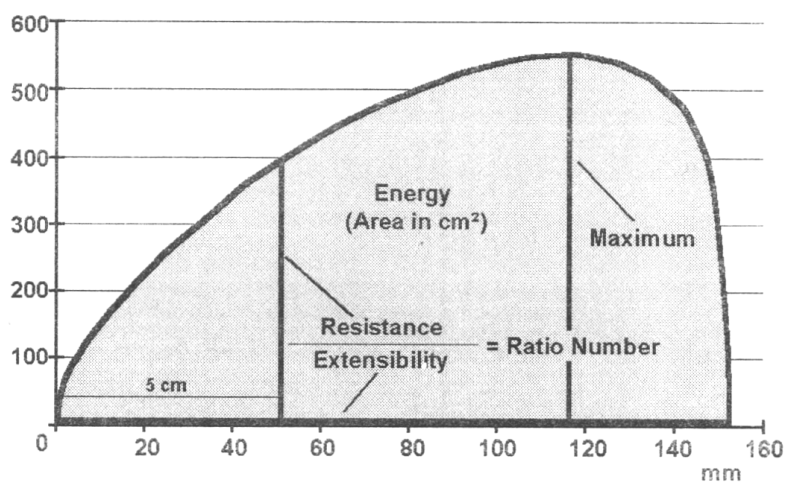

Fig. 5. General appearance of extensogram

At the studies, carried out using rotary viscosimeter Rheotest RN 4.1 the measuring system - cylinder-cone with rotor type $\mathrm{S} 1$ was used. The temperature of samples $32{ }^{\circ} \mathrm{C}$ was equal on the whole volume, the temperature variations were $0,1^{\circ} \mathrm{C}$ during experiment, the samples had the heterogenic consistence. The diapasons of shift speed $0,3-6,5 \mathrm{~s}^{-1}$ that the viscosity and tension of dough shift were determined at, were set before the start of measuring. The values of shift tension $(\theta)$ and system viscosity $(\eta)$ were determined during the study depending on the shift speed $(\dot{\gamma})$. The curves of dependence of the shift tension on the shift speed are approximated by Hershel-Bulkley function (2):

$$
\theta=\theta_{0}+\mathrm{k} \cdot \dot{\gamma}^{\mathrm{n}}
$$

where $\theta$ - shift tension, $\mathrm{kPa} ; \theta_{0}$ - flowability limit; $\mathrm{k}$ - consistence coefficient; $\mathrm{n}$ - flowability rate.

Processing of the results, carried out by the least squares method, allowed receive the dependence of effective viscosity on the shift speed (3):

$$
\eta_{\mathrm{E} \Phi}=\mathrm{a} \cdot \mathrm{e}^{\frac{\mathrm{b}}{\dot{\gamma}+\mathrm{c}}}
$$

where $\eta_{\mathrm{ef}}$ - effective viscosity, Pa·s; $\dot{\gamma}$ - shift speed, $\mathrm{s}^{-1} ; \mathrm{a}, \mathrm{b}, \mathrm{c}$ - empirical coefficients were calculated on the base of received experimental data (Table 4).

\section{Results}

The structural-mechanical and rheological properties of dough half-finished products, of the control and studied sample were studied in the work; the most rational DPCHFP concentration was $15 \%$ for the flour mass.

The results of digital deciphering of the dynamics of yeast dough creation with addition of DPCHFP, formation and destruction of its structure at the process of mechanical processing according to the data of farinograph «Brabender» are presented in the Table 3.

Table 3

\begin{tabular}{|c|c|c|c|c|c|c|}
\hline \multirow[b]{2}{*}{ Sample name } & \multicolumn{6}{|c|}{ Parameter name } \\
\hline & $\begin{array}{l}\text { Hydroscopic capacity, } \\
\qquad \mathrm{cm}^{3} / 100 \mathrm{~g}\end{array}$ & $\begin{array}{l}\text { Time of dough } \\
\text { creation, min }\end{array}$ & Stability, min & $\begin{array}{l}\text { Elasticity, } \\
\text { min }\end{array}$ & $\begin{array}{l}\text { Dilution during } \\
\text { mixing, units of } \\
\text { apparatus }\end{array}$ & $\begin{array}{l}\text { Dough consis- } \\
\text { tence, units of } \\
\text { apparatus }\end{array}$ \\
\hline \multicolumn{7}{|c|}{ Wheat flour (set № 1) } \\
\hline Control & 65 & 2,5 & 2,8 & 71 & 55 & 500 \\
\hline $15 \%$ DPCHFP & 71 & 3,0 & 4,0 & 79 & 45 & 500 \\
\hline \multicolumn{7}{|c|}{ Wheat flour (set № 2) } \\
\hline Control & 55 & 1,5 & 1,5 & 60 & 40 & 500 \\
\hline $15 \%$ DPCHFP & 63 & 2,0 & 3,0 & 67 & 32 & 500 \\
\hline
\end{tabular}

DPCHFP influence on dough creation 
The results of digital deciphering of extensogram are presented in the Table 4.

Table 4

DPCHFP influence on the dough properties according to Brabender's extensograph

\begin{tabular}{|c|c|c|c|c|}
\hline Sample name & $\begin{array}{l}\text { Resistance of stretching } \\
\text { (elasticity) } P_{r} \text {, units of ext }\end{array}$ & Extensibility L, mm & Energy, $\mathbf{c m}^{2}$ & $\begin{array}{l}\text { Ratio of stretching resistance } \\
\text { to extensibility } P_{r} / L\end{array}$ \\
\hline \multicolumn{5}{|c|}{ Wheat flour (set № 1) After 45.60 s fermentation } \\
\hline Control & 620 & 169 & 81,1 & 3,6 \\
\hline $15 \%$ DPCHFP & 690 & 165 & 89,3 & 4,2 \\
\hline \multicolumn{5}{|c|}{ After $90.60 \mathrm{~s}$ fermentation } \\
\hline Control & 600 & 178 & 78,0 & 3,3 \\
\hline $15 \%$ DPCHFP & 640 & 172 & 85,9 & 3,7 \\
\hline \multicolumn{5}{|c|}{ After $135 \cdot 60 \mathrm{~s}$ fermentation } \\
\hline Control & 570 & 197 & 67,5 & 2,8 \\
\hline $15 \%$ DPCHFP & 610 & 191 & 78,3 & 3,2 \\
\hline \multicolumn{5}{|c|}{ Wheat flour (set № 2) After 45.60 s fermentation } \\
\hline Control & 630 & 170 & 76,5 & 3,7 \\
\hline $15 \%$ DPCHFP & 670 & 164 & 82,5 & 4,1 \\
\hline \multicolumn{5}{|c|}{ After $90.60 \mathrm{~s}$ fermentation } \\
\hline Control & 540 & 181 & 70,5 & 2,9 \\
\hline $15 \%$ DPCHFP & 580 & 174 & 77,8 & 3,3 \\
\hline \multicolumn{5}{|c|}{ After $135.60 \mathrm{~s}$ fermentation } \\
\hline Control & 530 & 184 & 65,0 & 2,8 \\
\hline $15 \%$ DPCHFP & 570 & 176 & 73,6 & 3,2 \\
\hline
\end{tabular}

In the Table 5 are presented the experimental results of the study of effective viscosity $\eta_{\mathrm{E} \Phi}$ and the tension of dough samples shift $\theta$ depending on the shift speed.

Table 5

DPCHFP influence on the changes of effective viscosity and shift tension depending on the shift speed

\begin{tabular}{ccccc}
\hline \multirow{2}{*}{ Shift Speed, 1/s } & \multicolumn{2}{c}{ Control } & \multicolumn{2}{c}{ DPCHFP 15 \% } \\
& Effective viscosity, Pa·s & Shift tension, Pa & Effective viscosity, Pa·s & Shift tension, Pa \\
\hline 0,33 & 7350 & 2460 & 8920 & 3060 \\
0,88 & 4800 & 4210 & 5710 & 5020 \\
1,32 & 3810 & 5040 & 4830 & 6390 \\
1,83 & 2890 & 5300 & 4250 & 7530 \\
2,34 & 2420 & 5660 & 3550 & 8470 \\
2,85 & 2210 & 6300 & 3340 & 9520 \\
3,36 & 2060 & 6940 & 3070 & 10300 \\
3,87 & 2000 & 7720 & 3050 & 10680 \\
4,38 & 2030 & 8300 & 3030 & 11100 \\
4,89 & 1740 & 8520 & 2620 & 11100 \\
5,43 & 1530 & 8470 & 1840 & 10930 \\
5,92 & 1300 & 8250 & 1580 & 10740 \\
6,44 & 1170 & 7970 & 1210 & 10400
\end{tabular}

The aforesaid studies established that the better rates of structural-mechanical dough properties are typical to the samples with DPCHFP concentration $15 \%$. Thus, we find it expedient to add DPCHFP in quantity $15 \%$ for the flour mass because such concentration does not worsen organoleptic parameters, improves structural-mechanical and rheological properties of the dough. 
It was proved, that the studied samples of dough with DPCHFP have the stable structure that provide the absence of dough sticking on the working organs of technological equipment.

\section{Conclusions}

The elaborated accelerated technology of yeast dough using DPCHFP allows organize the output of wide assortment of products at enterprises of small capacity such as mini-bakeries, flour workshops in super-markets and at restaurant enterprises. And the chemical composition of additive allows also increase the food and biological value of the ready products.

In further researches it is planned to establish DPCHFP influence on rheological properties of dough at its fermentation and also to study the consumption properties of products, prepared by accelerated technology adding DPCHFP.

\section{References}

[1] Hager, A.-S., Zannini, E., Arendt, E. K. (2012). Formulating breads for specific dietary requirements. Breadmaking, 711-735. doi: 10.1533/9780857095695.4.711

[2] Lebedenko, T. E., KozhevnIkova, V. O., Sokolova, N. Yu. (2015). Modern ideas about the nutritional value of bakery products. The main directions of their correction. Grain products and mixed fodders, 2 (58), 19-25. doi: 10.15673/2313478x.58/2015.46011

[3] O’Regan, J., Ennis, M. P., Mulvihill, D. M. (2009). Milk proteins. Handbook of Hydrocolloids, 298-358. doi: 10.1533/9781845695873.298

[4] Singh, H. (2016). Functional Properties of Milk Proteins. Reference Module in Food Science. doi: 10.1016/b978-0-08-100596-5.00934-3

[5] Popova, S. Ju., Nykyforov, R. P., Slashcheva, A. V. (2015). Pre-activation optimization of the yeast. Technology audit and production reserves, 5 (4 (25)), 29-35. doi: 10.15587/2312-8372.2015.51760

[6] Korshunova, G. F., Nykyforov, R. P., Gnitsevich, V. A. (2007). Sposib otrimannya suhoyi sumishi. Pat. 27201. MPK CA23C 23/00, u200705242; declareted 14.05.2007; published 25.10.2007, Bul. 17.

[7] Hadiyanto, Asselman, A., Straten, G. van, Boom, R. M., Esveld, D. C., Boxtel, A. J. B. van. (2007). Quality prediction of bakery products in the initial phase of process design. Innovative Food Science \& Emerging Technologies, 8 (2), 285-298. doi: 10.1016/j.ifset.2007.01.006

[8] Ronda, F., Pérez-Quirce, S., Villanueva, M. (2017). Rheological Properties of Gluten-Free Bread Doughs: Relationship With Bread Quality. Advances in Food Rheology and Its Applications, 297-334. doi: 10.1016/b978-0-08-100431-9.00012-7

[9] Sanz, T., Salvador, A., Hernández, M. J. (2017). Creep-Recovery and Oscillatory Rheology of Flour-Based Systems. Advances in Food Rheology and Its Applications, 277-295. doi: 10.1016/b978-0-08100431-9.00011-5

[10] Heertje, I. (2014). Structure and function of food products: A review. Food Structure, 1 (1), 3-23. doi: 10.1016/j.foostr.2013.06.001

[11] Kinsella, J. E. (1987). Physical Properties of Food and Milk Components: Research Needs to Expand Uses. Journal of Dairy Science, 70 (11), 2419-2428. doi: 10.3168/jds.s0022-0302(87)80304-1

[12] Kneifel, W., Paquin, P., Abert, T., Richard, J.-P. (1991). Water-Holding Capacity of Proteins with Special Regard to Milk Proteins and Methodological Aspects-A Review. Journal of Dairy Science, 74 (7), 2027-2041. doi: 10.3168/jds.s0022-0302(91)78373-2

[13] Dotsenko, V. F., Ischenko, T. I., Shidlovska, O. B., Ivahno, O. O. (2006). Method of production of dietary wheat bread. Pat. 104091, MPK A21D 8/02, a 2012 12522; declareted: 02.11.2012; published 25.12.2013, Bul. 24.

[14] Zdobnov, A., Tsyiganenko, V. (2008), A collection of recipes food and cooking products for public catering enterprises. Kyiv, 680.

[15] Flour. Specifications 46.004-99 (1999). The State Consumer Standards of Ukraine, 9. 